\title{
Review of new systems and trends
}
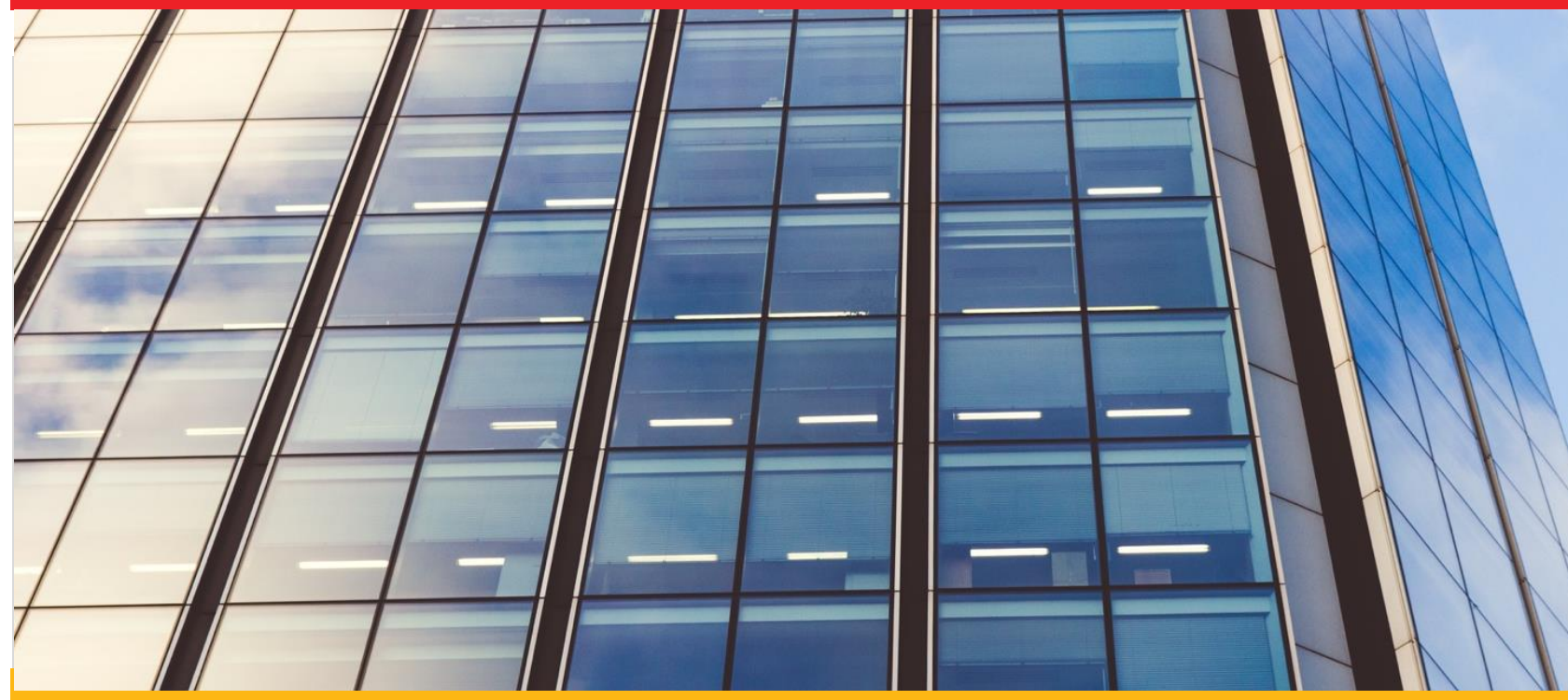

IEA SHC Task 61 / EBC Annex 77: Integrated Solutions for Daylighting and Electric Lighting 


\section{Solar Heating and Cooling Technology Collaboration Programme (IEA SHC)}

The Solar Heating and Cooling Technology Collaboration Programme was founded in 1977 as one of the first multilateral technology initiatives ("Implementing Agreements") of the International Energy Agency.

Our mission is "Through multi-disciplinary international collaborative research and knowledge exchange, as well as market and policy recommendations, the IEA SHC will work to increase the deployment rate of solar heating and cooling systems by breaking down the technical and non-technical barriers."

IEA SHC members carry out cooperative research, development, demonstrations, and exchanges of information through Tasks (projects) on solar heating and cooling components and systems and their application to advance the deployment and research and development activities in the field of solar heating and cooling.

Our focus areas, with the associated Tasks in parenthesis, include:

- Solar Space Heating and Water Heating (Tasks 14, 19, 26, 44, 54)

- Solar Cooling (Tasks 25, 38, 48, 53,65)

- Solar Heat for Industrial and Agricultural Processes (Tasks 29, 33, 49, 62, 64)

- Solar District Heating (Tasks 7, 45, 55)

- Solar Buildings/Architecture/Urban Planning (Tasks 8, 11, 12, 13, 20, 22, 23, 28, 37, 40, 41, 47, 51, 52, 56, 59, 63, 66)

- Solar Thermal \& PV (Tasks 16, 35, 60)

- Daylighting/Lighting (Tasks 21, 31, 50, 61)

- Materials/Components for Solar Heating and Cooling (Tasks 2, 3, 6, 10, 18, 27, 39)

- Standards, Certification, and Test Methods (Tasks 14, 24, 34, 43, 57)

- Resource Assessment (Tasks 1, 4, 5, 9, 17, 36, 46)

- Storage of Solar Heat (Tasks 7, 32, 42, 58, 67)

In addition to our Task work, other activities of the IEA SHC include our:

$>$ SHC Solar Academy

> Solar Heat Worldwide, annual statistics report

$>\mathrm{SHC}$ International Conference

\section{Our members}

Australia

Austria

Belgium

Canada

CCREEE

China

Denmark

EACREEE

ECREEE

European Commission
European Copper Institute

France

Germany

International Solar Energy Society

Italy

Netherlands

Norway

Portugal

RCREEE

SACREEE
SICREEE

Slovakia

South Africa

Spain

Sweden

Switzerland

Turkey

United Kingdom 



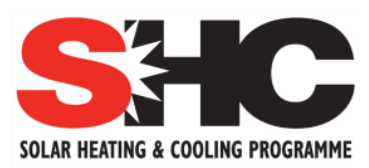

\section{Review of new systems and trends}

\section{Editor: Marc Fontoynont}

\section{Authors (in alphabetical order):}

Bruno Bueno Unzeta, Jan de Boer, Ruben Delvaeye, Nikodem Derengowski, Bertrand Deroisy, Marc Fontoynont, Daniel Neves Pimenta, Per Reinhold, Sophie Stoffer, Robert Weitlaner

\section{Date: October 2021}

\section{T61.B.3, A Technical Report of Subtask B} DOI: 10.18777/ieashc-task61-2021-0010

The contents of this report do not necessarily reflect the viewpoints or policies of the International Energy Agency (IEA) or its member countries, the IEA Solar Heating and Cooling Technology Collaboration Programme (SHC TCP) members or the participating researchers.

Cover image: (C) Pexels.com, Dom J. 

AUTHORS (in alphabetical order)

\begin{tabular}{|l|l|}
\hline Bruno BUENO UNZETA & Marc FONTOYNONT \\
Fraunhofer Institute for Solar Energy Systems & BUILD - Institut for Byggeri, By og Miljø \\
ISE & A.C. Meyers Vænge 15, \\
Heidenhofstr. 2, & 2450 København SV \\
79110 Freiburg i. Br. & Denmark \\
Germany & mfo@build.aau.dk \\
bruno.bueno@ise.fraunhofer.de & Daniel NEVES PIMENTA \\
Jan DE BOER & Fraunhofer Institute for Building Physics IBP \\
Fraunhofer Institute for Building Physics IBP & Nobelstr. 12, \\
Nobelstr. 12, & 70569 Stuttgart \\
70569 Stuttgart & Germany \\
Germany & daniel.neves.pimenta@ibp.fraunhofer.de \\
jan.deboer@ibp.fraunhofer.de & Per REINHOLD \\
Ruben DELVAEYE & Dansk Center for Lys (Danish Lighting Center) \\
Belgian Building Research Institute (BBRI) & Borupvang 9, \\
Avenue Pierre Holoffe, 21, & 2750 Ballerup \\
1342 Limelette & Denmark \\
Belgium & pr@centerforlys.dk \\
ruben.delvaeye@bbri.be & Sophie STOFFER \\
Nikodem DERENGOWSKI & BUILD - Institut for Byggeri, By og Miljø \\
BUILD - Institut for Byggeri, By og Miljø & A.C. Meyers Vænge 15, \\
A.C. Meyers Vænge 15, & 2450 København SV \\
2450 København SV & Denmark \\
Denmark & asls@build.aau.dk \\
derengowski.nikodem@gmail.com & Robert WEITLANER \\
Bertrand DEROISY & HELLA Sonnen- und Wetterschutztechnik \\
Belgian Building Research Institute & GmbH \\
Avenue P. Holoffe 21 & 9913 Abfaltersbach 125 \\
1342 Limelette & Austria \\
Belgium & robert.weitlaner@hella.info \\
bertrand.deroisy@bbri.be & \\
\hline & \\
\hline
\end{tabular}




\section{KEYWORDS}

Automation of lighting, integration, lighting control systems, value of lighting, glare-prevention, lighting trends

\section{ACKNOWLEDGEMENTS}

The authors thank their respective funding agencies for supporting their work:

Denmark: ELFORSK (Contract EUDP 64017-05110) 


\section{PREFACE}

Lighting accounts for approximately $15 \%$ of the global electric energy consumption and $5 \%$ of greenhouse gas emissions. Growing economies, higher user demands for quality lighting and rebound effects as a result of low priced and more versatile electric lighting continuously still lead to an absolute increase of lighting energy consumption. More light is used, often less consciously.

Especially the electric lighting market but as well the façade, daylighting und building automation sectors have seen significant technological developments in the past decade. However these sectors still act mainly independent of each other, leaving out big potentials lying in a better technology and market integration. This integration is on the one hand beneficial to providing better user-centred lighting of indoor spaces. On the other hand it can contribute significantly to the reduction of worldwide electricity consumptions and C02-emissions, which is in line with several different governmental energy efficiency and sustainability targets.

IEA SHC Task 61 / EBC Annex 77 "Integrated Solutions for daylighting and electric lighting - From Component to system efficiency" therefore pursues the goal to support and foster the better integration of electric lighting and daylighting systems including lighting controls with a main focus on the non-residential sector. This includes the following activities:

- Review relation between user perspective (needs/acceptance) and energy in the emerging age of "smart and connected lighting" for a relevant repertory of buildings.

- Consolidate findings in use cases and "personas" reflecting the behaviour of typical users.

- Based on a review of specifications concerning lighting quality, non-visual effects as well as ease of design, installation and use, provision of recommendations for energy regulations and building performance certificates.

- Assess and increase robustness of integrated daylight and electric lighting approaches technically, ecologically and economically.

- Demonstrate and verify or reject concepts in lab studies and real use cases based on performance validation protocols.

- Develop integral photometric, user comfort and energy rating models (spectral, hourly) as prenormative work linked to relevant bodies: CIE, CEN, ISO. Initialize standardization.

- Provide decision and design guidelines incorporating virtual reality sessions. Integrate approaches into wide spread lighting design software.

- Combine competencies: Bring companies from electric lighting and façade together in workshops and specific projects. Hereby support allocation of added value of integrated solutions in the market.

To achieve this goal, the work plan of IEA SHC Task 61 / EBC Annex 77 is organized according to the following four main subtasks, which are interconnected by a joint working group:

- Subtask A:

- Subtask B:

- Subtask C:

- Subtask D:

- Joint Working Group:

\author{
User perspective and requirements \\ Integration and optimization of daylight and electric lighting \\ Design support for practitioners (Tools, Standards, \\ Guidelines) \\ Lab and field study performance tracking \\ Evaluation tool \& VR Decision Guide
}

Subtask B focuses on the evolution of the technologies and identifies new opportunities offered by control systems for lighting and daylighting systems, with the objective to improve energy performance as well as improving operation by occupants and facility managers. 


\section{EXECUTIVE SUMMARY}

Innovative and integrative lighting solutions are a rapidly developing trend among BMS manufacturers. They are being implemented in various systems from industry-leading firms, however they are met with a challenge of finding the best possible compromise between occupant expectations and optimization of building operation.

This report describes relation between new trends and systems, the challenges associated with them, and the value creation that follows these innovative solutions.

The general discussion is followed by examples of 3 innovative systems from leading European brands and experts. Presented solutions are showing different possible directions in the development of new integrated solutions - integration of electric lighting and daylight-blocking blinds, integration of electric-lighting and blinds with the best possible solar gains and glare prevention at the workplaces, and innovative approach to implementing a glare prevention and human-centric lighting in the building's lighting system. Each of the three shown innovative systems is analysed with its' advantages and challenges. 


\section{Contents}

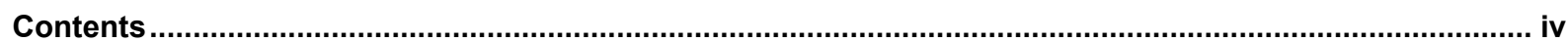

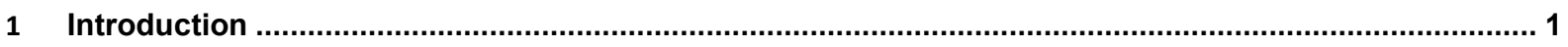

2 New value proposition associated to lighting control systems. .................................................... 1

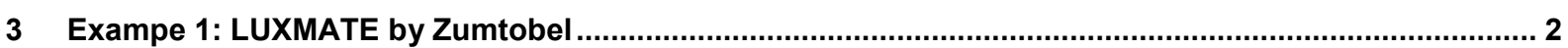

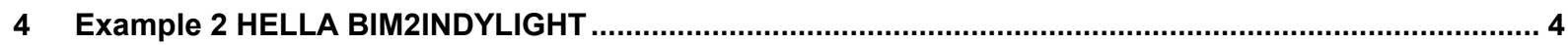

5 Example 3 HCL-CON (Human Centric Lighting - Control) .................................................................. 6

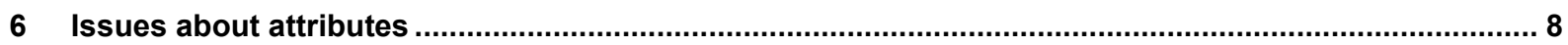




\section{Introduction}

Innovative solutions are met with the challenge of finding the best possible compromise between occupant expectations and optimization of building operation (low cost, low energy use, etc.)

The survey and the assessment of lighting control technologies presented in report B.1 identified key criteria of successful solutions:

a. Reliability (low maintenance)

b. Efficiency (for energy purpose)

c. Friendliness (user acceptance, simple interface)

d. Flexibility (allowing to adjust to evolution on needs)

e. Easy commissioning and re-commissioning

f. Future proof (system which could adapt to evolutions of technology over time)

g. Interoperability (linked to other control systems and services, simplifies management, data, etc.)

A clear distinction was made between the residential sector and the industrial and commercial buildings.

In homes, occupants control rather freely their light according to the various needs. Automatic controls concern mostly roller shades used for heat protection and security. Lighting controls have limited interest in living areas. However, they are currently used in common areas such as corridors and car parks in multistory apartment buildings.

On the other hand, in non-residential buildings, the key issues deal with energy performance, operation constraints, occupancy, and indoor light quality.

\section{New value proposition associated to lighting control systems.}

Controls with occupancy and daylight sensors can lead to around 30-60\% savings in lighting's power consumption depending of the type of spaces. However, when energy efficient lighting is deployed (luminous efficacy of luminaires higher than $100 \mathrm{~lm} / \mathrm{W}$ ), the associated annual financial gains are not that significant. This reduces the motivation for investing in control systems solely for reduction of the energy bill.

\begin{tabular}{|c|c|c|c|c|}
\hline $\begin{array}{c}\text { Electric Lighting } \\
\text { Power density } \\
\left(\mathrm{W} / \mathrm{m}^{2}\right)\end{array}$ & $\begin{array}{c}\text { Occupation of } \\
\text { building } \\
\text { Hours per year }\end{array}$ & $\begin{array}{c}\text { Savings related to } \\
\text { lighting controls } \\
\text { (for instance) }\end{array}$ & $\begin{array}{c}\text { Hours per year of } \\
\text { effective lighting }\end{array}$ & $\begin{array}{c}\text { Cost of Lighting } \\
\text { electricity per year } \\
@ 0,15 € / \mathrm{KWh}\end{array}$ \\
\hline 4 & 3000 & $50 \%$ & 1500 & $0,9 € / \mathrm{m}^{2} . \mathrm{yr}$ \\
\hline 8 & 3000 & $50 \%$ & 1500 & $1,8 € / \mathrm{m}^{2} . \mathrm{yr}$ \\
\hline
\end{tabular}


The table above shows that with modern lighting installations, savings due to lighting controls are high in proportion, but rather low in costs (around 1-1,5€/ $\mathrm{m}^{2} . \mathrm{yr}$ ). Note: the values above do not take into account possible gains in cooling loads, which are related to the reduction of the heat generated by the lighting installation.

This aspect shows that success of lighting controls is less related to energy performance (item b) from chapter 1 above) than all other criteria ( a) to g) ). Lighting controls can generate problems, but most of all can contribute to the value proposition of lighting, in relations to the list above.

In terms of value proposition associated to lighting controls, lighting controls can be seen as a technology which is a "Pain Reliever" (or problem solver), as well as a source of "Value Creation" (offering new business opportunities)

\begin{tabular}{|l|}
\hline \multicolumn{1}{|c|}{ Lighting control as a source of “Value Creation” (offering new business opportunities) } \\
\hline Control of specific lamps (wall washers, task, et.) \\
\hline New sensors and sensor location - Open loop / closed loop \\
\hline User-friendly, simple and attractive interface \\
\hline Full flexible module for control, beyond lighting (communication, displays, etc.) \\
\hline Glocalization services with lighting (LiFi) \\
\hline Easy commissioning and re-commissioning \\
\hline $\begin{array}{l}\text { Future proof (system which could adapt to evolutions of technology over time) - Updating through the } \\
\text { internet (new software) }\end{array}$ \\
\hline Interoperability (linked to other control systems and services, simplifies management, data, etc.) \\
\hline Making a house warmer during cold sunny days (intelligent shading controls) \\
\hline Making house cooler during warm sunny days \\
\hline Remote control from outside the building (facility management, user comfort) \\
\hline Anticipation of overheating: shading controls need to be more predictive and smarter (more data to collect) \\
\hline Flexibility can be related to future-proofing: update of systems \\
\hline Possibility to re-program the controls \\
\hline
\end{tabular}

Table: Analysis of lighting controls in relation with possible Value Proposition.

This business oriented approach explains a number of directions of innovative lighting controls systems. We present three of them below.

\section{Example 1: LUXMATE by Zumtobel}

The company Zumtobel has developed a system called: LUXMATE LITENET / PROFESSIONAL . It is a high-end room management system with lighting and blinds control, for an entire building. The product is characterized by the specific features described below: 


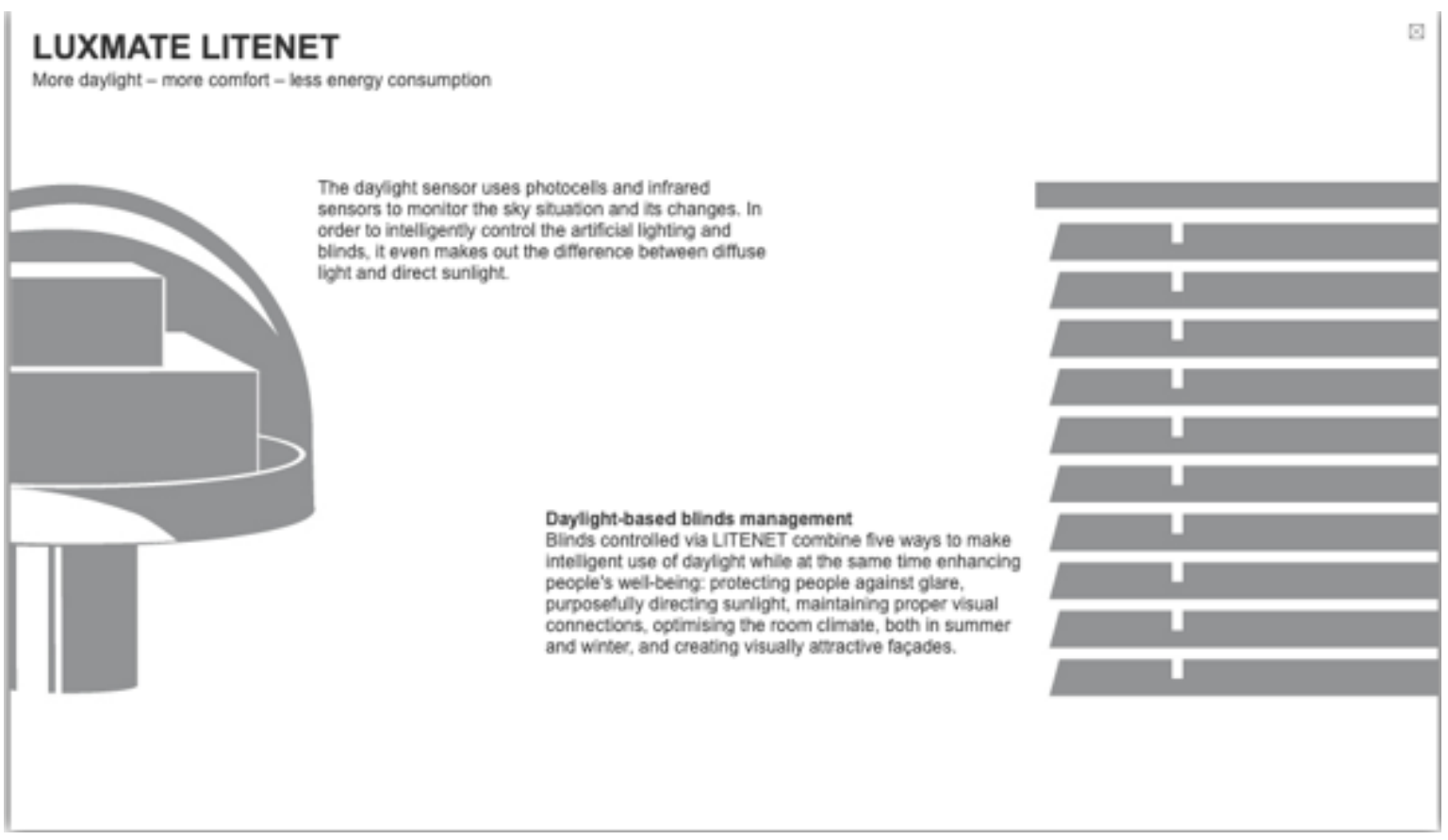

The outdoor sophisticated sensor tracks the power and the directionality of available daylight, and 5 options of blind positions are proposed to make the facades more homogeneous.

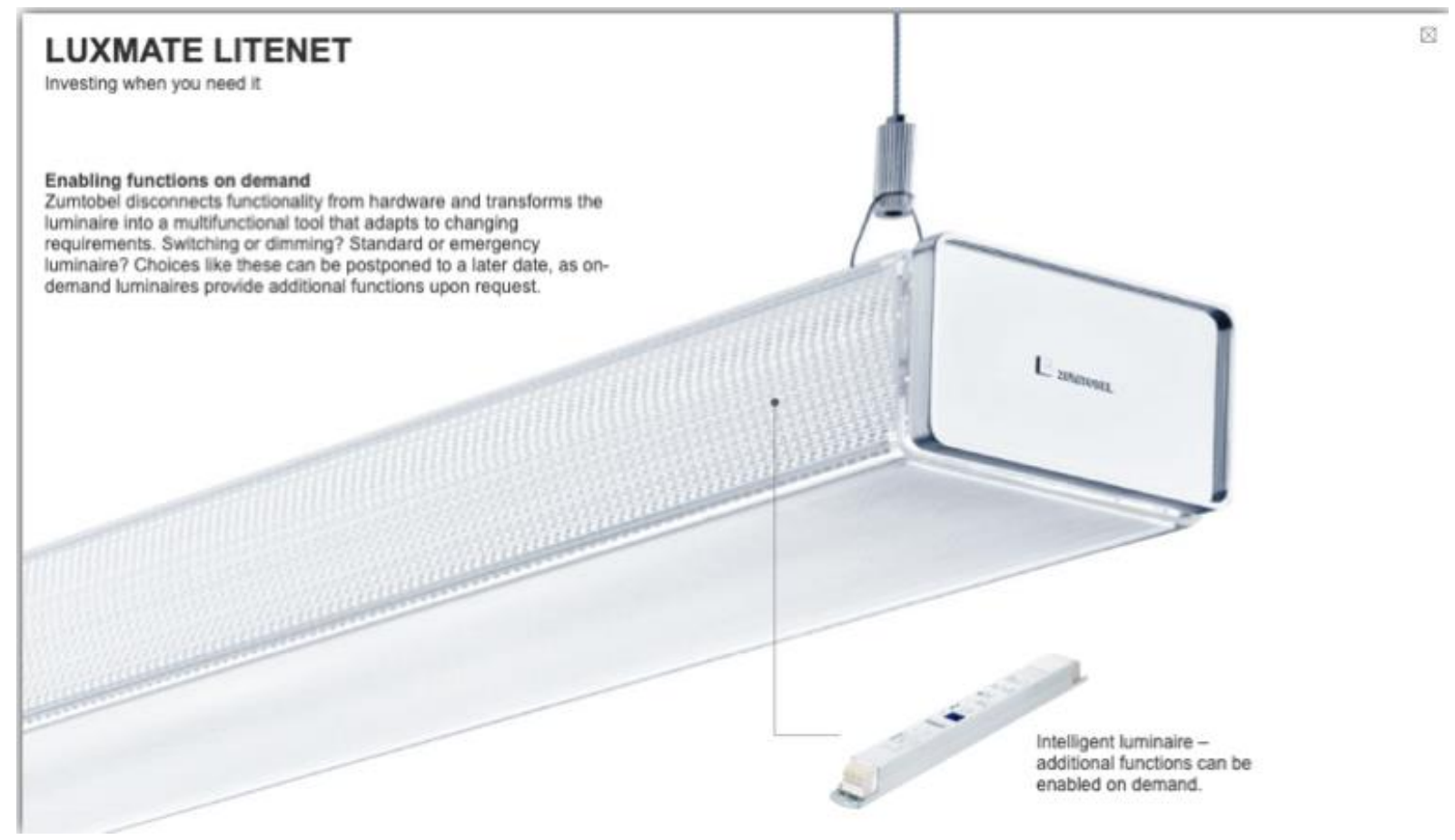

The same system is used to operate electric lighting upon a wide variety of options. 


\section{LUXMATE LITENET}

with TUNABLE WHITE

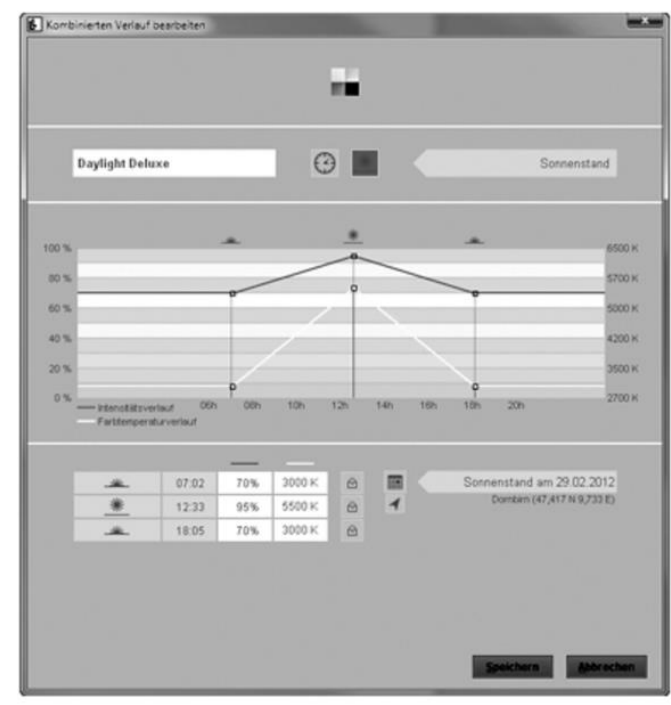

The LUXMATE LITENET Lighting Management System controls small building units as reliably as large-scale building complexes. Maximum energy efficiency can be achieved by intelligent integration of daylight sensors, presence detectors and time sensors. With the latest generation of the lighting management system, control of Tunable White luminaires has been smoothly integrated into the system.

What's special about it is that the luminaires' intensity and colour temperature can be set entirely independently and intuitively, on the basis of graphically displayed timelines. The lighting control system is supplied with the basic features of a beneficial lighting concept, including predefined sequences over the course of the day for offices, production facilities, healthcare facilities and retirement homes, based on the latest scientific findings. As these scenarios can be individually adjusted, and existing LITENET installations can be updated, energy-efficient lighting solutions with dynamic colour temperatures and luminous intensity levels can be implemented easily.

The LUXMATE system offers complete control over intensity and color temperature of all the compatible fixtures in the system. Moreover, there are predefined scenarios for different types of room use.

This example shows the feasibility of the system, but also the high sophistication needed to meet the performance criteria (human comfort, and energy performance). Is it worth developing a standard for describing such family of solutions? We can identify some issues: control protocol, performance and interfaces.

Attributes of the LUXMATE system:

\begin{tabular}{|l|l|}
\hline Component / strategy & Description \\
\hline Daylight sensor & $\begin{array}{l}\text { Outdoor, located on roof, provide data to all facades } \\
\text { Reading of illuminances (Ix) }\end{array}$ \\
\hline Motor of shading system & any \\
\hline Indoor sensor type & $\begin{array}{l}\text { Illuminance sensor in ceiling, looking downward, presence detectors } \\
\text { for workstations }\end{array}$ \\
\hline $\begin{array}{l}\text { Number of indoor } \\
\text { sensors }\end{array}$ & $\begin{array}{l}\text { Dependent on the size of the project and number of rooms and their } \\
\text { size - the system can operate in small offices with up to 500 } \\
\text { luminaries (output addresses), all the way up to large multi-story } \\
\text { office buildings with up to 10000 output addresses. }\end{array}$ \\
\hline
\end{tabular}

\section{Example 2 HELLA BIM2INDILIGHT}

In a research cooperation between solar shading and solar automation company HELLA, the University of Innsbruck, Unit of Energy Efficient Buildings, Bartenbach and ATP, a novel approach for a simulation-based open loop control named "IndiLight" was investigated. The model predictive 
control requires a model of the building structure (utilizing BIM datasets), a detailed façade specification for each state (BSDFs and angular dependent SHGCs), room interiors including illuminance reference points and view directions for each user, and the detection of the outdoor environment in terms of modelling (terrain and shadowing) and sensing (incident radiation).

The IndiLight control calculates the required artificial light to complement the existing daylight illuminance to the required illuminance levels for all possible states of the daylighting device (I.e. in case of a venetian blind tilt angle and percentage of extension) based on a pre-calculated database. A time-efficient calculation algorithm weighs the indicators daylight, artificial lighting energy, solar gains, comfort and non-visual effects according to predefined target functions in order to optimize the façade configuration for the actual weather- and indoor situation. The result per tilt angle is a pointwise illuminance level and the setpoint for the luminaires for an individual timestep.

An equivalent approach leads to tilt-wise solar gains per window, the tilt-wise glare indicator and non-visual indicator per predefined viewpoint.

\begin{tabular}{|c|c|c|c|c|}
\hline $\begin{array}{l}\text { Daylight } \\
\text { Illuminance }\end{array}$ & $\begin{array}{l}\text { Artificial Lighting } \\
\text { Power }_{\text {luminaire }}(\text { tilt) }\end{array}$ & $\begin{array}{c}\text { Solar } \\
\text { Gains } \\
\text { room(tilt) }\end{array}$ & DGP $P_{\text {viewpoint }}(t i l t)^{*}$ & $\begin{array}{c}\text { Non-Visual } \\
\text { Stimulus } \\
\text { oint(tilt) }\end{array}$ \\
\hline$[\mathrm{Ix}]$ & [W] & [W] & {$[-]$} & {$[-]$} \\
\hline at reference points & for each luminaire & per window & from viewpoints & $\begin{array}{c}\text { from } \\
\text { viewpoints }\end{array}$ \\
\hline per tilt angle & per tilt angle & per tilt angle & per tilt angle & per tilt angle \\
\hline
\end{tabular}

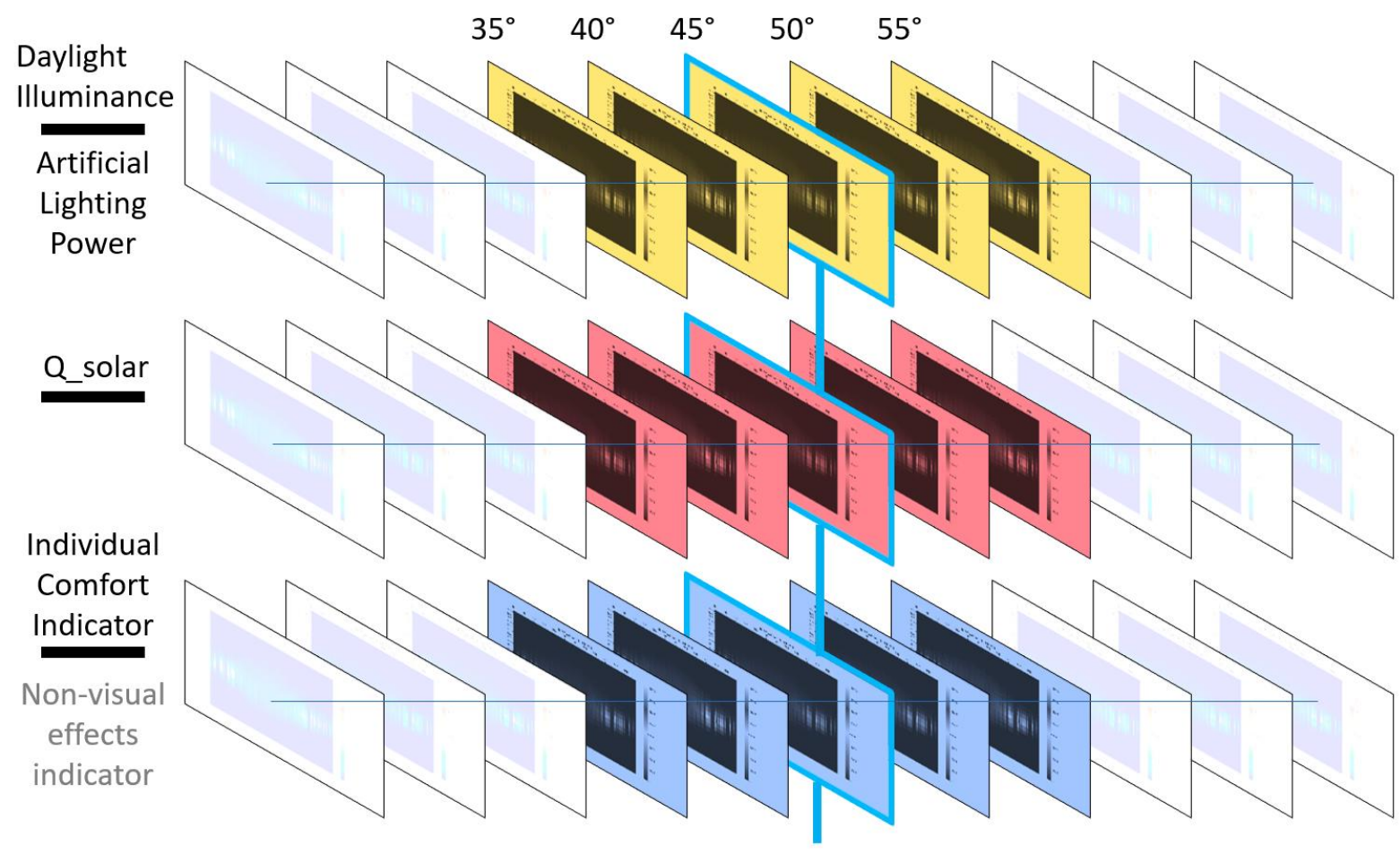

Best tilt 
The system analyses existing conditions and pre-calculated scenarios, and chooses the best tilt setting considering all the relevant factors.

\begin{tabular}{|l|l|}
\hline Component / strategy & Description \\
\hline Daylight sensor & $\begin{array}{l}\text { Irradiance outdoor located on roof, provide data to all facades } \\
\text { Reading of illuminances (Ix) }\end{array}$ \\
\hline Motor of shading system & any \\
\hline Indoor sensor type & Presence detection \\
\hline Number of indoor sensor & 0 \\
\hline Time step & 15 \\
\hline Modelling & High detailing required in modelling \\
\hline
\end{tabular}

\section{Example $3 \mathrm{HCL}-\mathrm{CON}$ (Human Centric Lighting - Control)}

Conventional lighting control systems currently do not detect and control the relevant parameters, but only horizontal illuminance levels, e.g. on the floor or table surface. However, the human eye (when standing or sitting) detects mainly in the horizontal range, so the vertical field of vision is decisive for user comfort. Determining factors are the luminance ratios, i.e. contrasts in the environment, on the screen and glare from the façade. A study (C. Moosmann, 2015) shows that glare control systems are mainly used to regulate daylight and hardly at all to regulate the indoor temperature, which has disastrous consequences in terms of energy. Human Centric Lighting Control "HCL-Con" addresses this issue with a new approach.
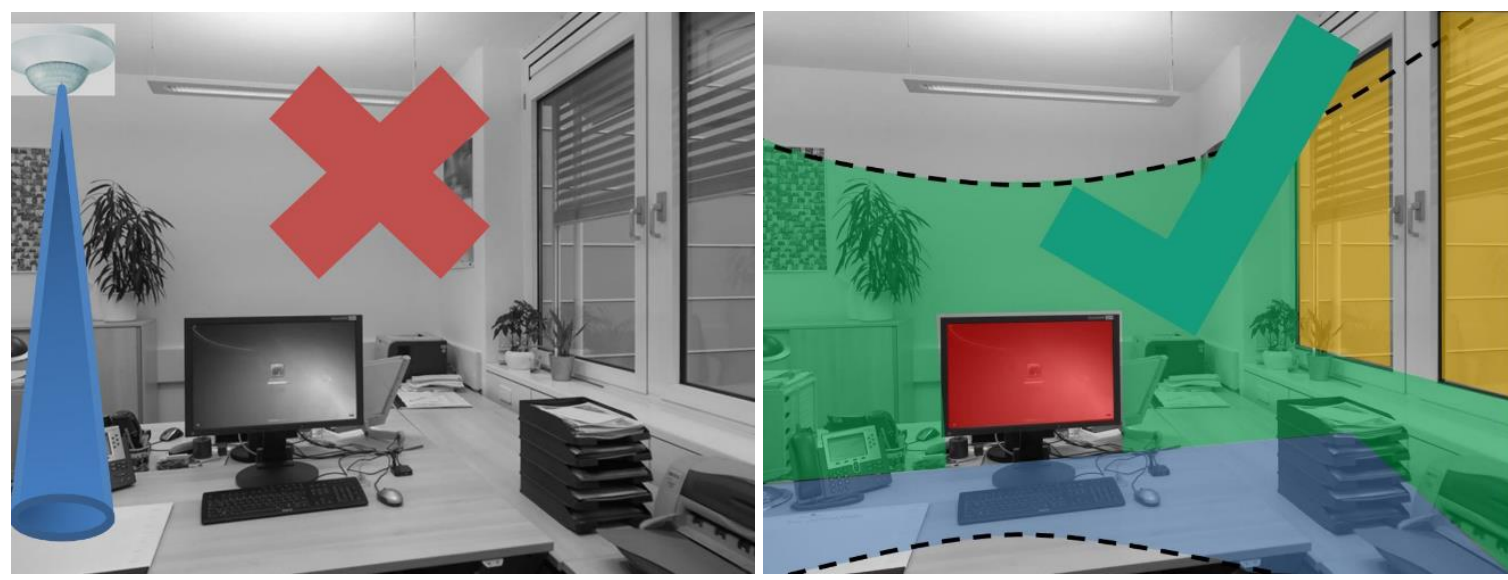

Conventional lighting controls detect and regulate horizontal illuminance levels (left), but the user comfort is predominantly in the vertical field of vision(right). (C) Fraunhofer IBP

The use of HCL-Con is intended to create ideal lighting conditions at the modern VDU workplace. In terms of functional, economic and visual aspects, added value is generated compared to solutions available on the market. 


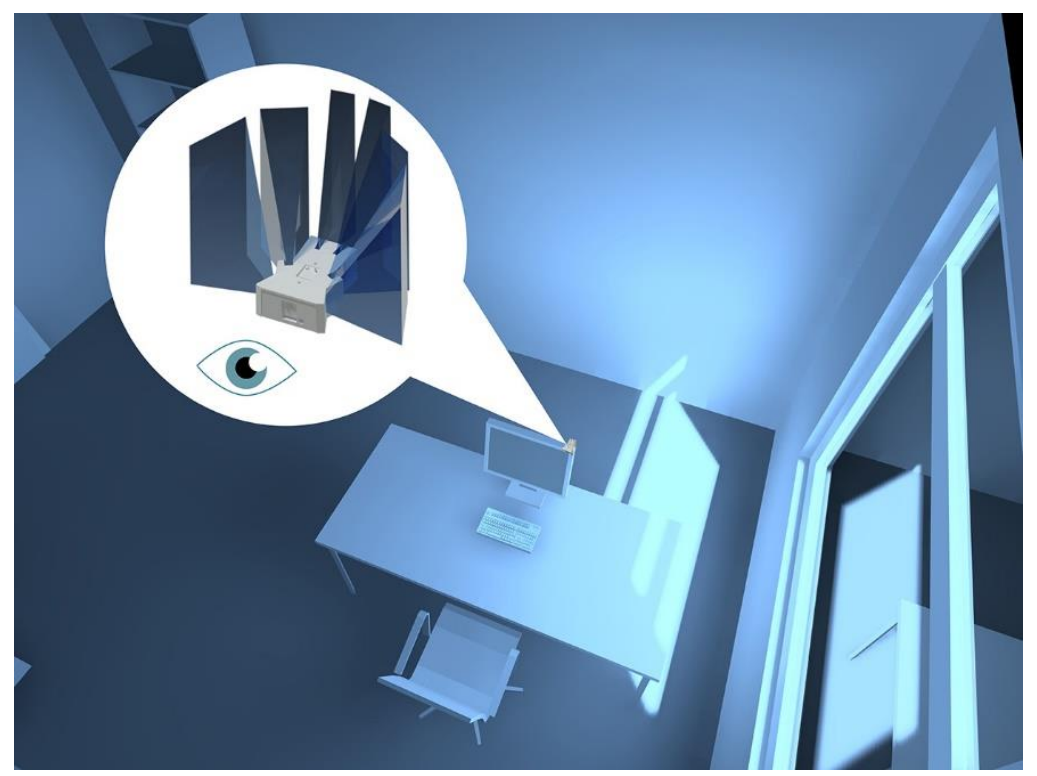

Concept of the HCL-Con sensor for the detection of vertical illuminance levels. (C) Fraunhofer IBP

The lighting environment at the VDU workstation changes in the course of the working day: daylight enters the room; the shading is lowered; artificial light is activated; the VDU switches off because no more input is made, etc. For the user, all these individual activities give a resulting lighting impression and an overall experience associated with it. Behind this, however, are control systems with several sensor locations and different limit values. In the current office situation, various deficits are to be solved by HCL-Con. These include, for example, the lack of acceptance of façade and screen control, the non-existent control of setpoints or the limit values that are not oriented towards user perception.
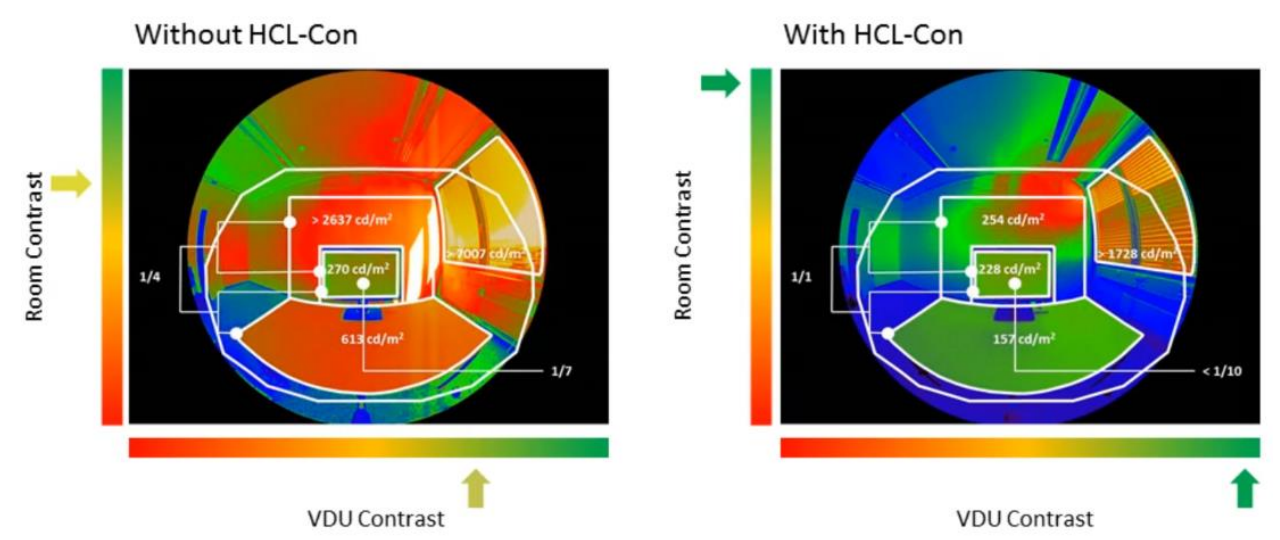

Lighting scenes with the same basic parameters were compared in pairs of images, each with conventional (inadequate) lighting control and with optimised HCL-Con lighting control. () Fraunhofer IBP

The concept has been validated by a proband study. Tests with self-developed prototypes in the Fraunhofer IBP laboratories show a significant increase in user comfort with higher energy efficiency. A patent for the process has been filed and talks are being held with interested parties from industry. The focus at Fraunhofer IBP is on the specification of the input variables and the development of the software, i.e., the algorithms for the ideal control of the various parameters. The concept can be implemented as an independent component, but also as an integral solution, i.e.., in screens or table lamps. 


\begin{tabular}{|l|l|}
\hline Component / strategy & Description \\
\hline Daylight sensor & $\begin{array}{l}\text { Indoor, located on Screen, horizontal, provide data from } 7 \text { direction, } \\
\text { all Reading of illuminances (Ix) }\end{array}$ \\
\hline Motor of shading system & KNX, BAK \\
\hline Indoor sensor type & $\begin{array}{l}\text { Located on Screen, horizontal, provide data from 7 direction, all } \\
\text { Reading of illuminances (Ix), vertical sensor measuring cct. }\end{array}$ \\
\hline $\begin{array}{l}\text { Number of indoor } \\
\text { sensors }\end{array}$ & $\begin{array}{l}\text { 1 device with } 6 \text { horizontal and one vertical sensors, Number of } \\
\text { devices is variable, depending on the number of Screens. }\end{array}$ \\
\hline
\end{tabular}

\section{Issues about attributes}

The presentation of the three innovative lighting - daylighting solutions shows directions and challenges that these systems are tackled with:

\begin{tabular}{|l|l|}
\hline Topic & Challenges \\
\hline Outside Sensor (open loop) & Reliability, design, PV powered, shading, \\
\hline Indoor sensor (closed loop) & Location, number \\
\hline Electric motor & Reliability, noise, steps, AC-DC, SMI \\
\hline Time step for actions (lighting / daylighting) & Performance vs user satisfaction \\
\hline Predictive mode & Anticipation of weather changes \\
\hline PV powered shading system & Autonomy level \\
\hline Tolerance issues & Acceptability by occupants \\
\hline Slat angle & Precision // tolerance of sun shading \\
\hline Commissioning & Tuning of system \\
\hline
\end{tabular}

